deals with structural engineering design problems; his particular interest is the structural interaction between the various elements of construction in multi-storey framed buildings. This interaction, or mutual stiffening of the parts of a building so as to strengthen the whole, has an important influence on building design, and Dr. Wood's work has contributed greatly to the understanding of the structural behaviour of complete buildings and to the more efficient allowance for composite action in structural design.

Similar promotions have been made by:

\section{(1) United Kingdom Atomic Energy Authority: Senior Principal Scientific Officers}

Mr. J. C. Martin has worked at the Atomic Weapons Research Establishment, Aldermaston, since its foundation in 1953. His early work was concerned first with small-scale explosives research, investigating the motion of fluid surfaces and later with the development and use of scintillation counters. More recently he has worked on neutron sources and on the development and application of sub-microsecond radiographic techniques for the experimental work on explosions. Starting with an early prototype $35-\mathrm{MeV}$. linear accelerator for which he developed a double focusing system, he has brought it to a state of output and reliability which has made it a valuable tool in the solution of certain hydrodynamic problems. He is now attempting to extend the flash X-ray technique from its present limit in the region of $1 \mathrm{MV}$. up to about $6 \mathrm{MV}$. He has contributed a number of original ideas in the field of advanced nuclear and thermo-nuclear weapons.

Dr. J. B. TAYLOR has worked at the Atomic Weapons Research Establishment, Aldermaston, for six years. He contributed first to the improvement of neutronic calculations used in the theory of explosions and in the computation of the stochastic behaviour of small populations in a supercritical system. He then carried out a number of investigations, ranging over several fields and at all levels of detail, to illuminate and help to direct the astrophysical engineering behind the megaton test series of 1957-58. He later worked on problems connected with fast reactors and on electromagnetic phenomena from explosions, before turning to problems of the thetatron and other controlled thermonuclear reactors.

\section{(2) Agricultura! Research Council: Deputy Chief Scientific Officer}

Dr. R. Markram joined the staff of the Plant Virus Research Station, Cambridge, now the Agricultural Research Council Virus Research Unit, in 1940 and became director of the Unit in 1960. His research has been concerned mainly with the biochemistry of the smaller plant viruses, and in 1949 he was able to demonstrate that the ribonucleic acid of the turnip yellow mosaic virus, which he and Dr. Kenneth Smith first isolated and purified, was necessary for the infectivity of the virus and was enclosed in a protective shell of protein. This work led to an intensive investigation of nucleic acids in general and resulted in the development of a large number of delicate methods for the analysis of nucleic acids and their constituents. It also led to an understanding of the way in which some of the enzymes which degrade nucleic acids, particularly pancreatic ribonuclease, act. Dr. Markham has also been concerned with synthetic mechanisms by which small polynucleotides can be made. He was elected a Fellow of the Royal Society in 1956.

\section{Senior Principal Scientific Officers}

Dr. C. H. Cadman is head of the Virology Department, Scottish Horticultural Research Institute, Mylnefield, Dundee, and is at present particularly concerned with the transmission of plant viruses by nematodes.

Dr. B. Kassanrs, of the Plant Pathology Department, Rothamsted Experimental Station, has discovered and described a number of viruses, and recently discovered that the multiplication of the virus depends on the simultaneous multiplication of another.

Dr. A. Kleczkowski, of the Plant Pathology Department, Rothamsted Experimental Station, is primarily a serologist, but has made substantial contributions to a range of subjects, and is now studying the surface structure of the protein units which make up tobacco mosaic virus.

\title{
THE ROYAL SCOTTISH MUSEUM
}

\author{
By DR. D. A. ALLAN, C.B.E. \\ Formerly Director
}

HE foundation stone of the Royal Scottish
Museum was laid by the Prince Consort in October
1861, and thereafter there arose in instalments the
Venetian Renaissance building which now occupies
more than half of Chambers Street, west of the Old
College, University of Edinburgh. It is a grey stone
structure consisting of a central block elongated east
and west, with two wings stretching southwards.
The area within was afterwards built on to yield a
series of rectangular halls, most of them with a main
ground-floor surmounted by two balconies, the earlier
ones supported on cast-iron pillars, the later either
cantilevered or upheld by ferro-concrete structures.
A 'grand staircase' was added at the rear in 1931,
with arches at its mezzanine landings to lead to a
prospective future block. A lecture hall had been included in the earliest part of the building but was later sacrificed to yield much-needed exhibition space, yet the necessity for a hall for lectures and demonstrations and later to provide educative film shows was ever present, and just before the Second World War foundations were dug beyond the 'grand staircase' for a rectangular lecture hall . . . and were left to be obliterated by ashes from the boilers. In May 1959 work was commenced on a theatre block of an entirely novel design, and its completion was achieved early in September 1961, the opening ceremony being performed by the Right Hon. the Earl of Rosse, chairman of the Standing Commission on Museums and Galleries, with the Right Hon. John Scott Maclay, H.M. Secretary of State for Scotland, in the chair. 


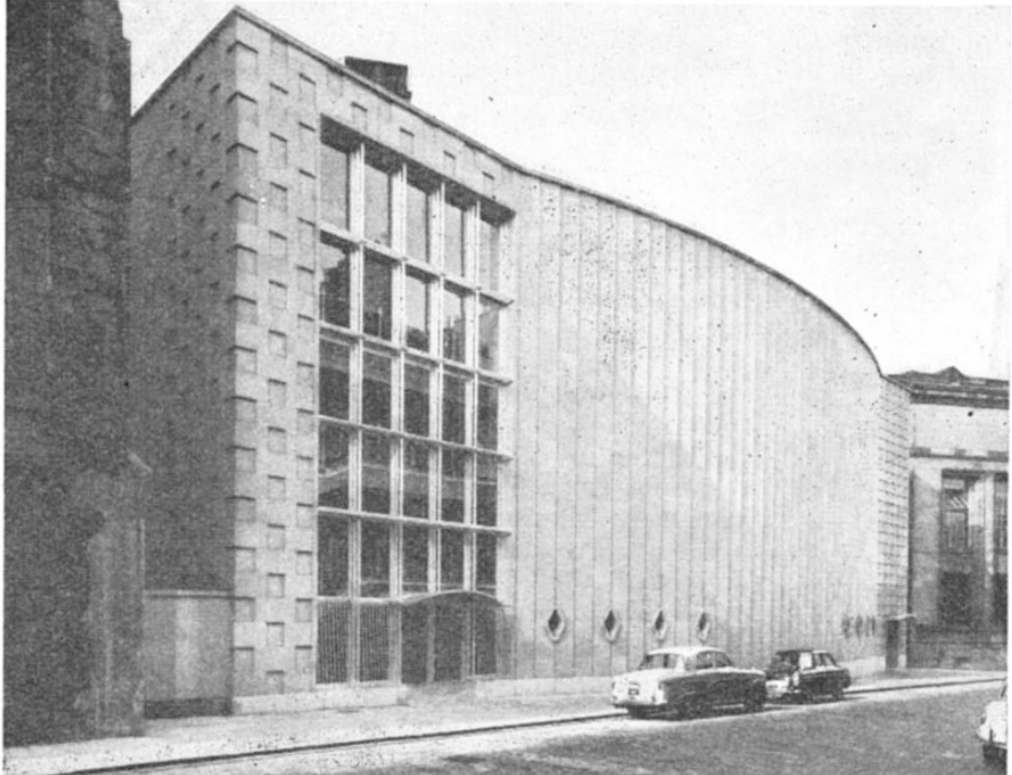

Fig. 1. The Royal Scottish Museum: New Theatre Block beam, with landings against an immense window rising the height of the building and facing the street. Because of differences in level, the foyer is broken across the middle and a short flight of curving steps leads from the new end to the old. The top-floor gallery opens on to an extensive exhibition hall over the lecture theatre, top lit and with an additional exit to the top of the emergency staircase. The proportions of the building can be put briefly and roughly-two-thirds width and two-thirds height for the lecture theatre, with the remaining third at the top exhibition hall and the remaining third at the side foyer with two overlying exhibition rooms. Underneath is a large cellar space, which will later be developed to advantage for much-needed storage. In contrast to the prevalence of right angles throughout the many halls of the old building, those in the new are limited to the contacts between floors and walls and walls and ceilings.

The site was a difficult one, being a triangle hemmed in by part of the back of the old building, a busy street and a little cul-de-sac. Again, whatever occupied it had to marry with a 1914 red sandstone somewhat classical façade of the Museum zoological galleries beyond and the grey sandstone of the Robert Adam Old College building further on.

The principal contribution being a lecture theatre, it had to be given the lion's share of the space, and the angle of the seating floor was determined by the number of persons to be accommodated. As the Museum's opening ceremonies attract around 200 guestis-and the early 1900 public lectures, organized by the Museum but housed in the adjacent University examination hall, as many as 250 -it was determined that the new theatre should hold 300. The plans allowed for this number of seats in ten curving rows of thirty, rising steeply on steps, with three aisles. The platform is low, long and narrow, so that everyone can have an uninterrupted view of speaker, demonstrations or of the screen occupying the central portion of the wall beyond. The back of the auditorium is against a solid bow-shaped, windowless street wall, impervious to light and sound. At the narrowing end of the triangle is an emergency staircase, with a side door at street-level. The wider end of the triangle is a threestoreyed block, each floor consisting of a curving chamber running from the street back to the older part of the building. The ground-floor is a foyer with a door to the street, another to the main museum building and the double sound-proof doors to the front of the auditorium. Above are two more floors, reached. by an open staircase of steps cantilevered on a single supporting

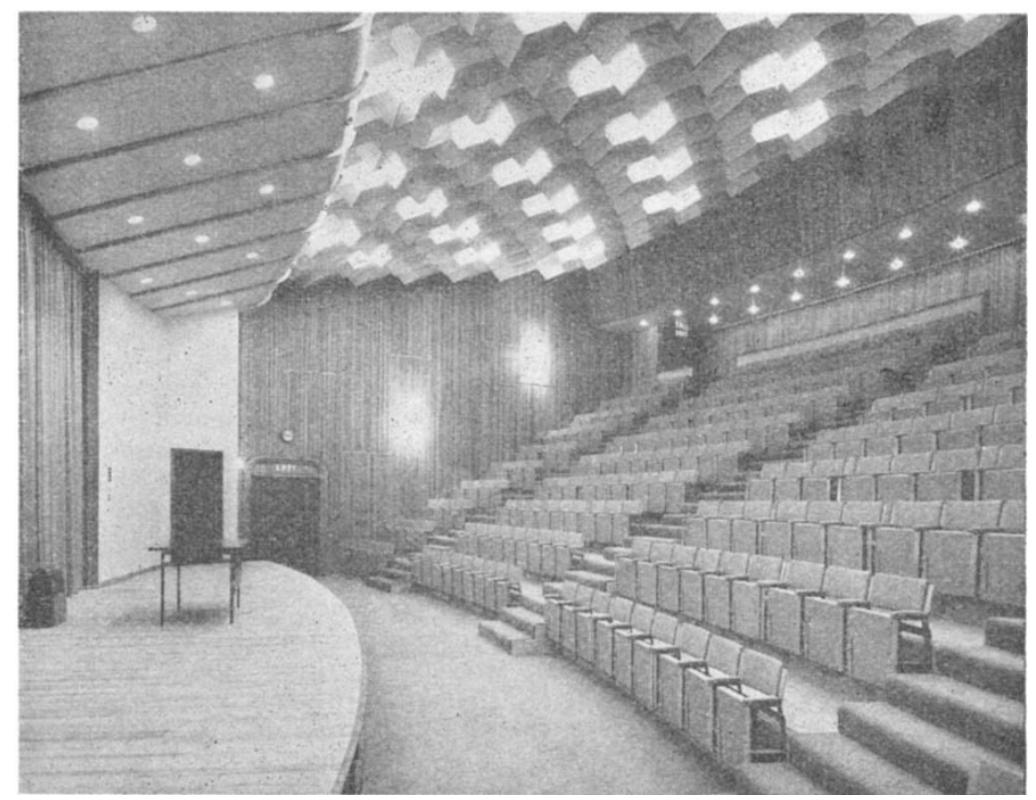

Fig. 2. New Lecture Theatre, Royal Scottish Museum
The lecture hall, which will be used for opening ceremonies connected with special exhibitions in the adjacent halls, conferences, lectures, school-class talks and cinema shows, presents a novel, modern and entirely charming interior, with its major sweep across its width, and the steeply tiered rows of tip-up chairs, upholstered in grey plasticized fabric, flanked and backed by walls lined to the full height with Abura wooden strips of a warm brown colour. The ceiling, which is also acoustically designed, presents a pattern of shallow rectangles in relief to the audience but projects a battery of lights from the unseen forward and downward projecting ends on to the platform. The lighting can be controlled either from the stage or from the projection room in the rear of 
the ceiling. The tiers and access gallery at the back are covered in grey marbled plastic flooring, with gold-coloured carpet on the three access stairways and blue carpet fronting the stage, the curtains of which are in gold. Hardwood strip has been used in the floors of the exhibition halls and travertine for the foyer. 'The 'flying' staircase is finished with hardwood treads with rubber inserts and aluminium; plate glass and plastic have been used for the balustrade. The architect has designed an appropriately carved teak door for the emergency exit. The designs begin at the base with early forms of life and fossils, pass up to various animals and man, show locomotives, telephones and television sets, and lead to a top row of aeroplanes, sputniks and an atomic explosion. The 'finale' is a row of question marks.

The exhibition halls are heated by low-pressure water coils contained within the floor. Background heating for the theatre is provided by coils behind the stage front and this will be supplemented when the hall is in use by warmed air introduced through the slats on the walls near the stage and extracted at the ceiling below the projection room. The 16-mm. projector is sited in a special room reached by a passage above and behind the auditorium. The building could well have taken a full-size projector, but in view of the difficulty of getting documentary films suitable for educational purposes, the smaller size had to be chosen.

The façade of the new extension is spectacular and modern, yet it provides a pleasing gradation with its neighbours. The bastion-like central mass consists of plain ribs of cream-coloured sandstone, reminiscent of a clinker-built boat, and standing on a simple polished granite base. In the lower portion of the sandstone are a few ovoid windows.

The curved central mass is flanked by two unequal flat walls, that to the east being smaller and having its square sandstone blocks split into two facets angled diagonally, so as to yield an attractive shadow pattern. The greater flank to the west is framed in square sandstone blocks with alternate ones set back to provide a different pattern, but the main face is a rectangular aluminium frame with a slightly arched doorway in the centre surmounted by five tiers of plain glass panes, the horizontel crossings marked by narrow bars which combine decoration with utility in supporting window cleaners. Through the glass, the stair landings add a decorative motif. The architect was Stewart Sim, a senior architect of H.M. Ministry of Works, and the contract was carried out by Thaw and Campbell, Ltd., Glasgow, at a cost of approximately $£ 120,000$. Thus the Royal Scottish Museum displays the march of time in its architecture and its furnishings -in its exhibits as well-over a full century.

\section{CANCER RESEARCH IN THE UNIVERSITY OF PERUGIA MEDICAL SCHOOL}

\section{BY Prof. LUCIO SEVERI \\ Director}

$\mathrm{O}^{\mathrm{N}}$ June 26, the occasion of the centenary celebrations of the chair of morbid anatomy of the University of Perugia, Dr. Thelma B. Dunn, head of the Cancer Induction and Pathogenesis Section, National Cancer Institute (U.S.A.), opened at Monteluce an extension to the Division of Cancer Research, University of Perugia Medical School.

The ceremony included $\boldsymbol{a}$ visit to the new animalhouse and the remodelled older one, on the main floor, in which normal work was in progress. The guests consisted essentially of the participants of the international conference on the "Morphological Precursors of Cancer". At the opening of the extension, all the doctors honoris causa of the University of Perugia Medical School were present, including Prof. A. Haddow, director of the Chester Beatty Research Institute, London; Prof. J. W. Orr, director of the Department of Pathology and Cancer Research Laboratories, University of Birmingham; Prof. J. J. Bittner, Division of Cancer Biology, University of Minnesota, Minneapolis; Dr. L. C. Strong, director of the Biological Section, Roswell Park Memorial Institute, Springville; Dr. J. R. Heller, president of the Memorial Sloan-Kettering Cancer Center, New York; Prof. C. Krauspe, director of the Institute of Morbid Anatomy, University of Hamburg; Prof. V. R. Khanolkar, vice-chancellor of the University of Bombay; and Prof. T. Yoshida, dean of the Faculty of Medicine, University of Tokyo.

The extension was designed by Prof. G. Nicolosi, Rome, and the work was carried out under the direction of Dr. G. Castori, Perugia, being erected by Messrs. Fioroni, Perugia, at a cost of 50,000,000 lire. The new accommodation doubles the previous floor area and makes the Division the largest and best equipped organization of its kind in Italy.

The extension consists of four storeys of concretecased steel-framed structure, faced with grey-coloured plaster. The various floors are formed with pre-cast concrete flooring units. The various services to the laboratories, which include hot and cold water, gas, electricity, compressed air, vacuum and steam, are visible, not concealed. In this way easy access is possible to the various services and pipe-lines when it is desired. Each floor is served by an automatic electrically operated passenger lift. The new building is linked with the older Division of Cancer Research by an underground passage, and contains extensive animal-house accommodation and laboratories for virology, tissue culture and cytogenetics.

The main financial responsibility of the Division of Cancer Research has always been borne by the University of Perugia. Additional funds are provided by the National Cancer Institute of the U.S. National Institutes of Health, and to a lesser, but valued, extent from the Lega Italiana per la Lotta contro i Tumori, Consiglio Nazionale delle Ricerche, Farmitalia Milano, and from other private Italian benefactions.

It is only since the Second World War that the idea of a Division of Cancer Research in the University of Perugia was conceived. But it was several years before the plan could be carried out. On November 30, 1952, the Minister of Public Education, on the occasion of the opening of the academic year, announced the establishment of a University Division of Cancer Research at Perugia. In the first building were established an animal 